\title{
調査報告
}

\section{日本における職場でのメンタルヘルスの第一次予防対策に関する 費用便益分析}

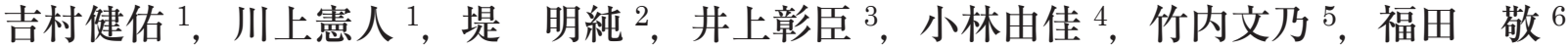 \\ 1 東京大学大学院医学系研究科精神保健学分野 \\ 2 北里大学医学部公衆衛生学 \\ 3 産業医科大学産業生態科学研究所精神保健学研究室 \\ 4 本田技研工業株式会社 \\ 5 東京大学大学院医学系研究科生物統計学分野 \\ 6 国立保健医療科学院研究情報支援研究センター
}

抄録：日本における職場でのメンタルヘルスの第一次 予防対策に関する費用便益分析：吉村健佑ほか. 東京 大学大学院医学系研究科精神保健学分野一目的: 本研 究では，職場に抒けるメンタルヘルスの第一次予防対 策の実施が事業者にとって経済的利点をもたらすかど うかを検討することを目的とし，すでに公表されてい る国内の研究を文献検索し, 職場環境改善, 個人向け ストレスマネジメント教育，打よび上司の教育研修の 3つの手法に関する介入研究の結果を二次的に分析し, これらの研究事例における費用便益を推定した。対象 と方法：Pubmed を用いて検索し，2011 年 11 月 16 日 の時点で公表されている職場のメンタルヘルスに関す る論文のうち，わが国の事業所で行われている事，第 一次予防対策の手法を用いている事，準実験研究また は比較対照を設定した介入研究である事, 評価として 疾病休業 (absenteeism)または労働生産性 (presenteeism) を取り上げている事を条件に抽出した結果，4論文が 該当した。これらの研究を対象に, 論文中に示され た情報および必要に応じて著者などから別途収集でき た情報に基づき，事業者の視点で費用抢よび便益を算 出した。解析した研究論文はいずれも労働生産性の 指標として HPQ (WHO Health and Work Performance Questionnaire) Short Form 日本語版，あるいはその一 部修正版を使用していた．介入前後での HPQ 得点の変 化割合を $\Delta \mathrm{HPQ}$ と定義し，これを元に事業者が得られ ると想定される年間の便益総額を算出した. 介入の効

2012 年 4 月 22 日受付； 2012 年 11 月 12 日受理 J-STAGE 早期公開日：2012 年 12 月 21 日

連絡先：吉村健佑

干 113-0033 東京都文京区本郷 7-3-1 東京大学大学院医学系研究科精神保健学分野 (e-mail: yoshimura-cib@umin.ac.jp)
果発現時期および効果継続のパターン， $\Delta \mathrm{HPQ}$ の $95 \%$ 信頼区間の 2 つの観点から感度分析を実施した。結果 : 職場環境改善では, 1 人当たりの費用が 7,660 円に対し， 1 人当たりの便益は点推定值に打いて 15,200-22,800 円 であり，便益が費用を上回った，個人向けストレスマネ ジメント教育では, 1 人当たりの費用が 9,708 円に対し， 1 人当たりの便益は点推定値において 15,200-22,920 円 であり，便益が費用を上回った，上司の教育研修では 2 論文を解析し, Tsutsumi et al. (2005) では 1 人当たりの 費用が 5,290 円に対し, 1 人当たりの便益は点推定值に おいて 4,400-6,600 円であり，費用と便益はおおむね同 一であった. Takao et al. (2006) では 1 人当たりの費用 が 2,948 円に対し， 1 人当たりの便益は 0 円であり，費 用が便益を上回った。 $\Delta \mathrm{HPQ}$ の $95 \%$ 信頼区間は，いず れの研究でも大きかった. 結論 : これらの研究事例に おける点推定值としては, 職場環境改善および個人向 けストレスマネジメント教育では便益は費用を上回り, これらの対策が事業者にとって経済的な利点がある可 能性が示唆された。 上司の教育研修では点推定值にお いて便益と費用は扮打むね同一であった。いずれの研 究でも推定された便益の $95 \%$ 信頼区間は広く，これら の対策が統計学的に有意な費用便益を生むかどうかに ついては, 今後の研究が必要である.

(産衛誌 2013; 55(1): 11-24)

doi: 10.1539/sangyoeisei.E12003

キーワード : Cost-benefit analysis, Japanese employees, Presenteeism, Primary prevention programs, Work performance, Workplace mental health 


\section{I. はじめに}

近年, 産業医学における精神保健の重要性は増して おり，我が国においてもうつ病をはじめとする精神疾 患を抱える社員は年々増加傾向にある ${ }^{1)}$ 。これを受けて 2006 年には厚生労働省より労働者の心の健康の保持増 進に関する指針 2) も出された。しかし，2007 年時点の 調査によると心の健康対策に取り組んでいる事業所は $33.6 \%$ に留まっている ${ }^{3)}$. 増加するメンタルヘルス不調 への対応として, 特に労働者のメンタルヘルス不調の 第一次予防対策に対する関心が高まりつつある4). しか し，その手法として科学的有効性が報告されている「職 場環境改善」「個人向けストレスマネジメント教育」「上 司の教育研修」の 3 つの活動 4 ) は，なお全事業所のそ れぞれ 7\%，17\%，12\%でしか実施されていない3)。心 の健康対策に取り組まない理由として，12.1\%の事業 所が「経費がかかる」と回答しており 3 ), 費用の問題 から対策が進まない側面も窥われる。また，対策に取 り組んでいる事業所でも心の健康対策の効果について $31.4 \%$ が「からない」と回答しており3)，事業者は明 確な対策の効果を見いだせないまま，十分な取り組み に踏み切れずにいる状況が推察される。

職場のメンタルヘルスの第一次予防対策の効果につ いては，抑うつ気分，不安など従業員の心理的ストレス 反応の低下を指標にして研究されることが多い.しかし 一方で, こうした精神健康指標に対する効果は, 事業者 にとっては理解しにくい．対策には費用がともなうこと から，事業者にとっては対策が企業の経営や業績にどの 程度影響したかがわからないと，対策の実施に強い動 機づけになりにくい. 職場のメンタルヘルスの第一次 予防対策の企業経営に及ぼす影響には, 過重労働によ る精神障害等の労働災害の防止など法的リスクのマネジ メント, 労働者の生産性の向上などさまざまな側面が ある ${ }^{4)}$. 近年特に, 産業保健において従業員の労働生産 性に注目した研究が増えている ${ }^{5)}$. 従業員の労働生産性 の評価対象としては，休業している状態 (absenteeism) と, 出勤しているが労働遂行能力が低下している状態 (presenteeism) の 2つが知られている6). 特に最近では presenteeismによる労働損失が大きいという報告がな されており7-9), わが国でも大うつ病性障害やアルコー ル依存症を患う労働者では, absenteeismによるよりも presenteeism による労働損失の影響が大きいという報告 がある 10)。こうした研究の蓄積は, 労働生産性の観点 からも産業保健活動を評価する視点につながってきてい る.これは職場のメンタルヘルスの第一次予防対策の効 果評価にも応用されるべき視点である.

医療経済評価のうち, 費用便益分析は費用と, 得ら れる結果 (便益) をすべて金銭で表して, 効率性を検討
する方法で, 費用便益比と純便益 (=便益一費用) を算 出することで, 比較対象がなくても意思決定の基礎と することができるという特徴を持つ ${ }^{11)}$. 事業者の視点 から産業保健領域での経済評価について 2,640 論文を検 討した系統的レビュー5)では，良くデザインされ，か つ精神保健に焦点を当てた研究は 2 論文 12,13) のみが取 り上げられている.このうちの 1 つである Lo Sasso ら (2006) の研究 12) では absenteeism および presenteeism の観点から労働者のうつ病治療に対する費用便益分析 が行われている.もう1つの Smootら (1995) の研究 13) では, 離職, 休業, 業務パフォーマンスへの影響の観 点から精神科病棟に勤務するスタッフに対し, 入院患 者とのコミュニケーション技術訓練を行うことでプラ スの費用便益が得られることが報告されているが, 同 研究は精神科患者とのコミュニケーションという治療 的技術を身につけることに対する費用便益分析であり， 職場のメンタルヘルスという視点からの研究とは言え ない. 以上より, 明確に従業員の第一次予防に焦点を 当てて行われた費用便益分析の報告は見られていない のが現状である.

本研究では第一次予防対策の実施が事業者にとっ ての経済的利点をもたらすかどうかを検討すること を目的とし，すでに公表されている国内の研究から absenteeism あるいは presenteeism に対する介入効果の 報告されている介入研究を文献検索し, 職場環境改善, 個人向けストレスマネジメント教育, および上司の教 育研修の 3 つの手法に関する先行研究の結果を二次的 に分析することで，事業者の視点で第一次予防対策の 方法別費用便益分析を実施した. 本研究では, 各研究 の元データまでさかのぼって再解析をすることは一般 的に困難であることから, 各研究における費用便益の 点推定を事例として報告し，職場のメンタルヘルスの 第一次予防対策の費用便益の目安となる情報を提供す ることを主目的とした。しかし，可能な範囲で費用便 益の 95\% 信頼区間についても計算した。本研究により, 各手法の費用便益および手法間の比較が明らかとなり， 事業場における職場のメンタルヘルスの第一次予防対 策の普及につながることが期待される.

\section{II. 対象と方法}

\section{1. 分析対象論文の抽出}

Pubmed を用いて研究論文を検索し，2011 年 11 月 16 日の時点で, キーワード ( “stress, psychological” [MeSH Terms] OR ("stress" [All Fields] AND "psychological" [All Fields]) OR “psychological stress” [All Fields] OR ( "mental” [All Fields] AND "stress" [All Fields]) OR “mental stress” [All Fields]) AND performance[All 
Fields] AND ( “japan” [MeSH Terms] OR “japan” [All Fields])にて該当した 118, および ( “mental health” [MeSH Terms] OR ("mental” [All Fields] AND "health" [All Fields]) OR “mental health" [All Fields]) AND performance[All Fields] AND ( “japan” [MeSH Terms] OR “japan”[All Fields]) にて該当した 125 文献（重複 あり)をリストアップした。 これらの文献とその引用 文献のうち関連があると考えられる文献を著者が精查 し，わが国の事業所で行われている事，第一次予防対 策の手法を用いている事, 準実験研究または比較対照 を設定した介入研究である事, 評価として疾病休業 (absenteeism) または労働生産性 (presenteeism)を取り 上げている事を条件に抽出した結果, 4 論文が該当した. なお, 医学中央雑誌刊行会 Web を用い, 同条件で検索 したところ条件に該当した論文はなかった。また，関 連すると思われる国内文献を可能な限り検索を行った が，条件に該当した論文はなかった，以上より，上記 の 4 論文 14-17) を本研究の解析対象とした４論文のう ち, Tsutsumi ら (2009) ${ }^{14)}$ は職場環境改善を用いた無作 為化比較試験であり, 職場環境改善における費用便益 分析の対象とした. Umanodan ら (2009) ${ }^{15)}$ は個人向け ストレスマネジメント教育を用いた比較対照試験であ り, 個人向けストレスマネジメント教育における費用 便益分析の対象とした。Tsutsumi ら (2005) ${ }^{16)}$ は準実験 研究, また Takao ら (2006) ${ }^{17)}$ は無作為化比較試験によ る上司の教育研修の効果評価であり, これら 2 論文を 上司の教育研修の費用便益分析の対象とした.

\section{2. 費用便益分析}

これらの研究を対象に，論文中に示された情報およ び必要に応じて著者などから別途収集できた情報に基 づき，事業者の視点で費用および便益を算出した。

1) 費用の算出

研究論文の記述と, 可能な場合には著者への聞き取 りから, 介入に必要な費用の総額と介入群の従業員 1 人あたりの費用を算出した．費用のうち大きな部分を占 めるのは, 従業員や管理監督者などのプログラムに参 加時の賃金である. 賃金の算出根拠として, 平成 22 年 厚生労働省賃金構造基本統計調查 ${ }^{18)}$ より一般従業員年 収 435 万円（うち賞与額は 80 万円 : 年収の $18.4 \%$ ) 時給 2,000 円 (男女平均年収を参照), 管理職年収 880 万円 (うち賞与額は 210 万円: 年収の $23.9 \%$ ) 時給 4,000円 (大 学大学院卒 - 管理事務技術労働者, 勤続年数 25-29 年 を参照）と概算した。 また, 教育講師費用については 産業保健専門職 10 名から意見聴取を行い, 1 回あたり 30 分程度で 1.5 万円, 60 分程度で 3 万円, 120 分程度 で 5 万円， 240 分程度で 7 万円と設定して概算した．各 研究とも異動や脱落などが見られたが, 異動・脱落者
も含め介入群全員の費用を算出した.

2) 便益の算出

解析した研究論文はいずれも労働生産性の指標と し $\tau$ HPQ (the WHO Health and Work Performance Questionnaire) ${ }^{19,20)}$ Short Form 日本語版 (付録参照), あるいはその一部修正版を使用していた．先行研究に よると製造業, サービス業, 会社幹部などの多様な職 種において, HPQを用いての自己記入による労働生産 性と上司からの客観的評価による労働生産性の間に十 分な一致が報告されている19,20)。今回の解析では, 介 入前後の労働生産性の指標の変化割合を用いて便益を 計算した．労働生産性の指標は 0 点 $=\lceil$ 最悪の出来 」か ら, 10 点 $=\lceil$ 最高の出来」で表現されている. 一部修 正版では，指標の範囲を 0-100 点までとしていた.

便益の算出根拠となる賃金は, 人事労務担当者など からの意見聴取に基づき, 年間給与のうち賞与額のみ とした。これは身分保障的な側面の強い月給給与に比 べて, 賞与額は事業場における労働生産性の合計や企 業の収入・収益とある程度の相関をもつと考えられる ためである。

介入前後での HPQ 得点の変化割合を以下のように $\Delta \mathrm{HPQ}$ と定義し，これを元に事業者が得られると想定 される年間の便益総額を算出した.

$\Delta \mathrm{HPQ}=\frac{\text { 介入群後值 }- \text { 介入群前值 })-(\text { 対照群後値 }- \text { 対照群前値 })}{\text { (介入群前值 }+ \text { 対照群前值 }) / 2}$ 便益総額 $=\Delta \mathrm{HPQ} \times$ 介入人数 $\times$ 年間賞与額 $($ 一般従業員 80 万円 $)$

なお, 異動や脱落によりデータが得られなかった場 合は介入群, 対照群とも該当者の $\Delta \mathrm{HPQ}=0$ と仮定し て便益を算出した。 また, 1 年単位での解析としたた め, 便益の時間割引は調整不要であった。関連する結 果として，便益総額， 1 人当たり便益に加え， 1 人当た り費用から 1 人当たりの便益を減じた 1 人当たり純便 益, 1,000 人当たり純便益, 費用に対する便益の比 (ROI: return on investment）を算出した.

3) 休業日数の変化に対する補正

4 つの研究のうち, 職場環境改善を用いた介入研究で ある Tsutsumi ら (2009) ${ }^{14)}$ では, 著者から介入群, 対照 群の介入前, 1 年後の休業日数のデータの提供を受けた. これ以外の 3 つの研究では休業日数のデータが得られ なかったので, 計算に含めなかった. 休業日数を含めた 場合の $\Delta \mathrm{HPQ}$ を求めるための基礎資料として, 平成 23 年厚生労働省就労条件総合調査 ${ }^{21)}$ より国内の年次有給 休暇の利用状況 8.6 日, 年間休日日数 113.0 日を入手し た.これによれば年間所定労働日数は 365-113.0=252.0 日であり, これから 8.6 日の年次有給休暇を差し引いた 上に, さらに介入群, 対照群の増加休業日数を差し引 
くと, 各群の出勤日数が計算できるとし，これらの出 勤日数には $\triangle \mathrm{HPQ}$ 分だけ労働生産性が増加することか ら, 休業日数を含めた修正 $\Delta \mathrm{HPQ}$ を以下の計算式によ り求めた。

$\Delta \mathrm{HPQ}(\mathrm{revised})=\frac{(252-8.6-\text { 介入群の増加休業日数 }) \times(1+\Delta \mathrm{HPQ})}{(252-8.6 \text {-刘照群の増加休丵日数 }) \times 1}-1$

4) 感度分析

$2 つ の$ 観点から感度分析を実施した。

(1) 効果発現の時期および効果継続のパターン

職場環境改善 14) については, 図 1 に示す通り事前調 查時の 12 ケ月後である事後調查時の介入効果が最大で あり，これを 1.0 としたとき，効果は介入後直線的に漸 増すると考元，6 ケ月後の介入効果を(1) 0.5 とした場合 と，6r月後ですでに最大の効果に達していると考えこ れを(2)1.0とした場合の2通りについて便益を算出した.

個人向けストレスマネジメント教育 ${ }^{15)}$ ，打よび上司 の教育研修のうち Tsutsumi ら $(2005)^{16)}$ についても, 複 数の感度分析を行った. 図 2 に示す通り事前調查時の 約 6 ケ月後である事後調查時の介入効果が最大であり, これを 1.0 としたとき，その後 12 ヶ月後にかけて効果 が漸減すると仮定し，12 ケ月後には効果が(1)なし $(0.0)$ まで低下するとした場合，(2) 1/3 (0.33) まで低下すると した場合，(3)2/3 (0.67) まで低下するとした場合，(4)低 下せずに保持される (1.0) とした場合の 4 通りについて 便益を算出した。

\section{(2) $\triangle \mathrm{HPQ}$ の $95 \%$ 信頼区間}

今回の研究では, いずれの論文も調查個票は得られ なかったため, 論文中に示された $\mathrm{HPQ}$ 得点の点推定值 および標準誤差 $(\mathrm{SE})$ を用いて $\Delta \mathrm{HPQ}$ の $95 \%$ 信頼区間 （95\%CI）を推計した。またこの推計をもとに便益の 95\%信頼区間を算出した。

\section{III. 結 果}

\section{1. 職場環境改善}

1) 研究の概要

Tsutsumi ら (2009) の研究は，国内のある製造工場に おいて行われた 14$)$ 。事業所规模は 14 職場 $(\mathrm{n}=139)$ ，で あるが 3 職場 $(\mathrm{n}=42)$ は職場組織の変更のため不参加 であり, 11 職場 $(\mathrm{n}=97)$ が研究に参加した。職場単位 で，無作為に介入群と対照群に割り付けを実施した．6 職場 $(n=47)$ が介入群となり, 従業員参加型職場環境改 善が寒施された。 5 職場 $(\mathrm{n}=50)$ が対照群となった。盲 検化は実施していない。論文の記載内容から，2005 年 5 月に介入群の各職場からファシリテーター 1 名ずつ選 抜し，計 6 名に対してファシリテーター教育を行った こととした。2005 年 7 月に介入群・対照群ともに事前

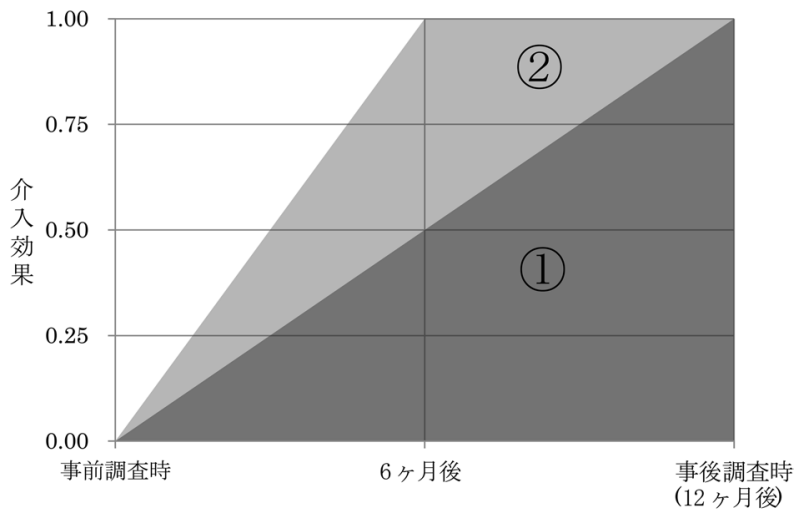

図 1. 職場環境改善 14)における2 種類の感度分析. 縦軸 の介入効果は事前調査時を 0.0 とし，12 ケ月後であ る事後調查時の介入効果を 1.0 としたもの. 6 ケ月 後の介入効果を(1) 0.5 とした場合と, (2) 1.0 とした 場合を想定した。それぞれグラフの下側面積は年間 の総介入効果となる。それぞれグラフの下側面積は 年間の総介入効果となる.

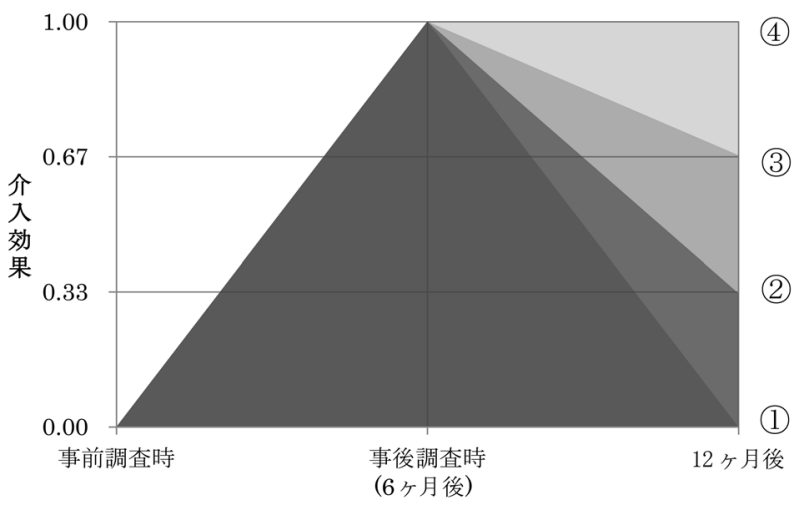

図 2. 個人向けストレスマネジメント教育 ${ }^{15)}$, および上司 の教育研修のうち Tsutsumi らの研究 16)における4 種類の感度分析. 縦軸の介入効果は事前調査時を 0.0 とし, 介入 6 ケ月後 (事後調査時) の介入効果を最 大と考え 1.0 とした. 12 ケ月後の介入効果は漸減し (1) 0.0 となるとした場合, (2) 0.33 となるとした場合, (3) 0.67 となるとした場合, (4) 1.0 のままとした場合 を検討した。それぞれグラフの下側面積は年間の総 介入効果となる。

調査を実施した。 2005 年 10 月に, 介入群の職場管理 職 6 名に対し職場環境改善に関する意義の説明を行っ たこととした。 2005 年 11 月に, 介入群に対し職場環 境改善を目的とした参加型研究集会（講義および集団討 論）を実施した。2 回の事後研究集会を行い, 2006 年 8 月に介入群・対照群ともに事後調査を実施した。ここ で，著者への聞き取り調査により，各職場のファシリ 


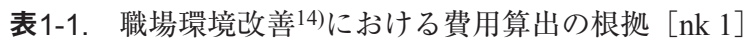

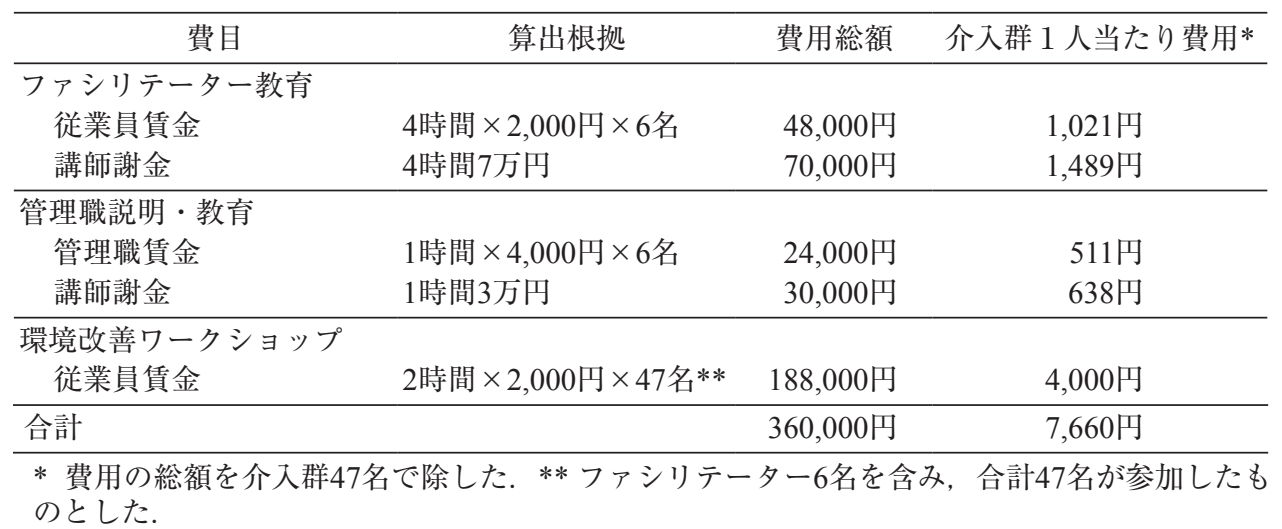

表1-2. 職場環境改善14)における便益, 純便益およびROI

\begin{tabular}{lcc}
\hline & 感度分析1 & 感度分析(2) \\
\hline 便益総額 (円) & $714,400^{*}[-206,800,1,654,400]$ & $1,071,600^{* *}[-310,200,2,481,600]$ \\
1人当たり便益 (円) & $15,200[-4,400,35,200]$ & $22,800[-6,600,52,800]$ \\
1人当たり純便益(円) & $7,540[-12,060,27,540]$ & $15,410[-14,260,45,140]$ \\
1,000 人当たり純便益 (万円) & $754[-1,206,2,754]$ & $1,541[-1,426,4,514]$ \\
ROI*** & $1.98[-0.57,4.60]$ & $2.98[-0.86,6.89]$ \\
\hline
\end{tabular}

ๆ感度分析(1)(2)定義は図1に示した通り。介入群47名として1人当たりの便益, 純便益を算出した. 算出根拠としては， $\Delta \mathrm{HPQ}[95 \% \mathrm{CI}]=3.8 \%[-1.1 \%, 8.8 \%]$ を用い，点推定值 $[95 \%$ 信頼区間 $(\mathrm{CI})]$ を算出し た。 * 80 万 $\times 47$ 名 $\times 0.038 \times 1 / 2$.**80万 $\times 47$ 名 $\times 0.038 \times 3 / 4$. *** ROI: return on investment（費用に対 する便益の比).

テーター教育の参加人数が計 12 名, 職場管理職への説 明の参加人数が計 12 名との情報を得た。実際にはこの ような状況で実施されたが，これは今回の研究の特殊 事情である。一般の現場で実施される場合を想定して, 今回の分析では，ファシリテーター教育の参加人数が 計 6 名, 職場管理職への説明の参加人数が計 6 名とし て解析を行った。この研究の結果, HPQの増加に対し て有意な介入効果が報告されている。 介入群と対照群 の HPQ についての群と時点を要因とする 2 元配置分 散分析を実行し，その交互作用項が有意であった（F 值 $=4.05, p=0.048$ )

\section{2) HPQ 変化量の算出}

介入群 47 名のうち，12 名は異動等にて脱落し，4名 は最終評価が行えなかった。解析が行えた 31 名につい ては，介入前後の HPQ はそれぞれ 65.1 (SD 12.3), 67.3 (SD 10.3) であり, 変化量は +2.2 (paired $t$-test: $t=-0.95$, $p=0.348)$ であった．対照群 50 名のうち, 8 名が異動 等にて脱落し， 3 名は最終評価が行えなかった. 解析 が行えた 39 名については介入前後の HPQ はそれぞ れ 66.9 (SD 7.9), 63.8 (SD 9.3) であり変化量は -3.1 (paired $t$-test: $t=2.13, p=0.040$ ) であった. 以上に基づい て $\Delta \mathrm{HPQ}$ を計算すると以下となる。
$\Delta \mathrm{HPQ}=\frac{(31 \times 2.2+16 \times 0) / 47^{-[39 \times(-3.1)+11 \times 0] / 50}}{(65.1+66.9) / 2}=0.0586(\mathrm{SE} 0.0258)$

また，著者への聞き取り調査により，介入前後の休 業日数の変化について, 介入群 47 名中 32 名の年間休 業日数が介入前 3.09 日であったのが, 介入後 6.31 日に 3.2 日増加し, 対照群 50 名中 41 名の年間休業日数が介 入前 4.95 日であったのが, 介入後 3.37 日に 1.6 日減少 との結果を得た。ここで全ての介入群, 全ての対照群 は, それぞれ上記と同一の年間休業日数であると仮定 し, $\Delta \mathrm{HPQ}$ の補正を行った.

$\Delta \mathrm{HPQ}($ revised $)=\frac{(252-8.6-3.2) \times 1.059}{(252-8.6+1.6) \times 1.00}-1=0.03825(\mathrm{SE} 0.0253)$ $\Delta \mathrm{HPQ}($ revised:95\%CI) $=[-0.0113,0.0878]$

3) 費用の算出

費用総額および介入群 47 名で除した 1 人当たり費用 を表 1-1 に示した。介入群 1 人当たりの費用 7,660 円の うち，従業員・管理職の賃金は 5,533 円 (72\%) であり, 講師謝金は 2,127 円 (28\%) であった。

4) 便益の算出

便益総額, 介入群 47 名で除した 1 人当たり便益, 1 人あたり純便益， 1,000 人当たり純便益および費用に対 する便益の比 (ROI) を表 1-2 に示した. 介入効果の発 現時期については図 1 に示した感度分析を行い, それ 
表2-1. 個人向けストレスマネジメント教育（合計6回）15)における費用算出の根拠

\begin{tabular}{lccc}
\hline 費目 & 算出根拠 & 費用総額 & 介入群 1 人当たり年間* \\
\hline 従業員賃金 & 0.5 時間 $\times 2,000$ 円 $\times 482$ 名** & 482,000 円 & 5,021 円 \\
講師謝金 & 30分 1.5 万円 $\times 6$ 回 $\times 5$ 職場 & 450,000 円 & 4,687 円 \\
\hline 合計 & & 932,000 円 & 9,708 円 \\
\hline *費用の総額を介入群である96名で除した. & $* *$ ストレスマネジメント教育への延べ参
\end{tabular}

加人数 482 名であった.

表2-2. 個人向けストレスマネジメント教育15)における便益，純便益およびROI

\begin{tabular}{lcccc}
\hline & 感度分析1 & 感度分析(2) & 感度分析(3) & 感度分析(4) \\
\hline 便益総額 (円) & $1,459,200 *$ & $1,702,400 * *$ & $1,945,600 * * *$ & $2,188,800 * * * *$ \\
& {$[-691,200,3,609,600]$} & {$[-806,400,4,211,200]$} & {$[-921,600,4,812,800]$} & {$[-1,036,800,5,414,400]$} \\
1人当たり便益 (円) & 15,200 & 17,827 & 20,373 & 22,920 \\
& {$[-7,200,37,600]$} & {$[-8,400,43,867]$} & {$[-9,600,50,133]$} & {$[-10,800,56,400]$} \\
1人当たり純便益 & 5,492 & 8,119 & 10,665 & 13,212 \\
(円) & {$[-16,908,27,892]$} & {$[-18,108,34,159]$} & {$[-19,308,40,425]$} & {$[-20,508,46,692]$} \\
1,000 人当たり 純便益 & 549 & 812 & 1,067 & 1,321 \\
(万円) & {$[-1,691,2,789]$} & {$[-1,811,3,416]$} & {$[-1,931,4,043]$} & {$[-2,051,4,669]$} \\
\hline ROI $^{* * * * *}$ & $1.57[-0.74,3.87]$ & $1.84[-0.87,4.52]$ & $2.10[-0.99,5.16]$ & $2.36[-1.11,5.81]$ \\
\hline
\end{tabular}

ๆ 感度分析(1)(2)(4)の定義は図 2 に示した通り。介入群 96 名として 1 人当たりの便益, 純便益を算出した。算出根拠と しては $\Delta \mathrm{HPQ}[95 \% \mathrm{CI}]=3.8 \%[-1.8 \%, 9.4 \%]$ を用い，点推定值 $[95 \%$ 信頼区間 $(\mathrm{CI})]$ を算出した. * 80 万 $\times 96$ 名 $\times 0.038 \times$ $1 / 2 . * * 80$ 万 $\times 96$ 名 $\times 0.038 \times 7 / 12 . * * * 80$ 万 $\times 96$ 名 $\times 0.038 \times 2 / 3 . * * * * 80$ 万 $\times 96$ 名 $\times 0.038 \times 3 / 4 . * * * * *$ ROI: return on investment（費用に対する便益の比).

ぞれ $95 \%$ 信頼区間を示した。点推定值に基づく 1 人当 たりの純便益は 7,540-15,410 円，ROI は 1.98-2.98 で あったものの，便益の $95 \%$ 信頼区間はいずれも 0 を跨 いでいた.

2. 個人向けストレスマネジメント教育

\section{1) 研究の概要}

Umanodan ら (2009) の研究は，国内のある製鉄事業 場において行われた ${ }^{15)}$ 。研究対象は 7 職場 $(\mathrm{n}=182)$ で ありその全てが研究に参加した．職場単位で介入を受 けるか否かの意思を確認した。介入を受けることに同 意した 5 職場 $(n=105)$ のうち事前調査を拒否した 9 名 を除外し， 5 職場 $(\mathrm{n}=96)$ が介入群と割り付けられ，従 業員に対し個人向けストレスマネジメントが実施され た。介入を受ける事に同意しなかった 2 職場 $(n=77)$ の うち事前調査を拒否した 24 名を除外し， 2 職場 $(n=53)$ が対照群と割り付けられた。無作為化および盲検化は 実施されていない. 2006 年 10 月に介入群・対照群とも に事前調查を実施した。 2006 年 10 月から 2007 年 4 月 にかけて介入群である 5 職場それぞれに対し毎月 1 回 の計 6 回, 1 回 30 分間の個人向けストレスマネジメン 卜教育講習を実施した。 2007 年 4 月に介入群・対照群 ともに事後調查を実施した．介入群 96 名のうち，3名 は調査データが得られず，49名は講習の一部分のみに
参加した. これらを除く完遂者 44 名と対照群との比 較では, 心理的ストレス反応に加え, HPQ 得点の改善 に有意な介入効果が報告されている. 介入群と対照群 の介入後の HPQ 得点について, 介入前值を共変量と した共分散分析にて有意な群間差を認めている（F值 $=3.755, p=0.047)$.

2) HPQ 変化量の算出

上記の完遂者 44 名を解析の対象とした. 介入前後 の HPQ はそれぞれ 6.1 (SD 2.0), 6.6 (SD 2.0) であり変 化量は +0.5 (SD 1.4) であった. 対照群 53 名のうち, 2 名はデータが得られず解析から除外した。解析を行っ た 51 名については介入前後の HPQ はそれぞれ 5.9 (SD 2.2), 5.9 (SD 2.2) であり変化量は 0.0 (SD 1.6) であった. 以上に基づいて $\Delta \mathrm{HPQ}$ を計算すると以下となる．休業 日数は不明であるため, 計算に算入しなかった。

$\Delta \mathrm{HPQ}=\frac{(44 \times 0.5+52 \times 0) / 96^{-}(51 \times 0+2 \times 0) / 53}{(6.1+5.9) / 2}=0.03819(\mathrm{SE} 0.02846)$ $\Delta \mathrm{HPQ}(95 \% \mathrm{CI})=[-0.0176,0.0938]$

3) 費用の算出

従業員の時給については, 部分的な参加にとどまっ た従業員も含めた延べ参加人数について総プログラム 費用の一部として算出した。費用総額および介入群 96 名で除した 1 人当たり費用を表 2-1 に示した。介介入群 1 
表3-1. 上司の教育研修のうちTsutsumiらの研究16)における費用算出の根拠

\begin{tabular}{|c|c|c|c|}
\hline 費目 & 算出根拠 & 費用総額 & 介入群 1 人当たり年間* \\
\hline 管理職賃金 & 2.25 時間 $\times 4,000$ 円 $\times 232$ 名 $* *$ & 2,088,000円 & 4,723円 \\
\hline 講師謝金 & 2.25時間5万円×5回 & 250,000円 & 566円 \\
\hline 合計 & & 2,338,000円 & 5,290円 \\
\hline
\end{tabular}

*費用の総額を介入群442名で除した。**高出席率職場の上司の参加人数は 232 名であった。

表3-2. 上司の教育研修のうちTsutsumiらの研究16)における便益, 純便益およびROI

\begin{tabular}{|c|c|c|c|c|}
\hline & 感度分析 (1) & 感度分析(2) & 感度分析(3) & 感度分析(4) \\
\hline 便益総額（円） & $\begin{array}{c}1,944,800^{*} \\
{[-1,326,000,5,127,200]}\end{array}$ & $\begin{array}{c}2,268,933^{* *} \\
{[-1,547,000,5,981,733]}\end{array}$ & $\begin{array}{c}2,593,067^{* * *} \\
{[-1,768,000,6,836,266]}\end{array}$ & $\begin{array}{c}2,917,200^{* * * *} \\
{[-1,989,000,7,690,800]}\end{array}$ \\
\hline 1人あたり便益（円） & $4,400[-3,000,11,600]$ & $5,133[-3,500,13,533]$ & $5,867[-4,000,15,467]$ & $6,600[-4,500,17,400]$ \\
\hline $\begin{array}{l}\text { 1人あたり純便益 } \\
\text { (円) }\end{array}$ & $-890[-8,290,6,310]$ & $-157[-8,790,8,243]$ & $577[-9,290,10,177]$ & $1,310[-9,790,12,110]$ \\
\hline $\begin{array}{l}\text { 1,000人あたり純便益 } \\
\text { (万円) }\end{array}$ & $-89[-829,631]$ & $-16[-879,824]$ & $58[-929,1,018]$ & $131[-979,1,211]$ \\
\hline $\mathrm{ROI}^{* * * * *}$ & $0.83[-0.57,2.19]$ & $0.97[-0.66,2.56]$ & $1.11[-0.76,2.92]$ & $1.24[-0.85,3.29]$ \\
\hline
\end{tabular}

ๆ 感度分析(1)(2)(4)の定義は図 2 に示した通り. 介入群 442 名として 1 人当たりの便益, 純便益を算出した. 算出根拠としては, $\Delta \mathrm{HPQ}[95 \% \mathrm{CI}]=1.1 \%[-0.75 \%, 2.9 \%]$ を用い，点推定值 $[95 \%$ 信頼区間 $(\mathrm{CI})]$ を算出した。 * 80 万 $\times 442$ 名 $\times 0.011 \times 1 / 2$. ** 80 万 $\times 442$ 名 $\times 0.011 \times 7 / 12$. *** 80 万 $\times 442$ 名 $\times 0.011 \times 2 / 3$.**** 80 万 $\times 442$ 名 $\times 0.011 \times 3 / 4$. ***** ROI: return on investment（費用に対する便益の比).

人当たりの費用 9,708 円のうち，従業員の賃金は 5,021 円 $(52 \%)$ であり,講師謝金は 4,687 円 (48\%) であった.

4) 便益の算出

便益総額, 介入群 96 名で除した 1 人当たり便益, 1 人あたり純便益, 1,000 人当たり純便益および費用に対 する便益の比（ROI）を表 2-2 に示した。 介入効果の持 続期間については図 2 に示した感度分析を行い，それ ぞれ $95 \%$ 信頼区間を示した。点推定值に基づく 1 人当 たりの純便益は 5,492-13,212 円， ROI は 1.57-2.36で あったものの，便益の $95 \%$ 信頼区間はいずれも0を跨 いでいた。

\section{3. 上司の教育研修}

3-1. Tsutsumi ら (2005) ${ }^{16)}$ の結果

1) 研究の概要

Tsutsumi ら (2005) の研究は, 1,644 名の職員を持つ 国内のある自治体において行われた ${ }^{16)}$. 上司は 473 名, 一般職員は 1,171 名であった。一般職員のうち 593 名 はデー夕不十分であり除外した。デー夕を得た一般職 員 $(n=578)$ を, 上司の $1 / 3$ 以上が参加した「高出席率職 場」(n=442) を介入群と割り付け, 上司の参加が $1 / 3$ 以 下であった「低出席率職場」(n=136) を対照群として割 り付けて比較した。無作為化および盲検化は実施して いない. 2002 年 11 月に介入群・対照群ともに事前調査 を実施した。 2002 年 11 月から 2002 年 12 月にかけて, 5 回に分けて 90 分の講義と 45 分の参加型研修からなる 同一の内容で上司教育プログラムを実施し，各上司は 1
回，任意で参加することとし，合計 267 名 $(56 \%)$ の上 司が参加した. 2003 年 3 月に介入群 ・対照群ともに事 後調査を実施した。結果として, 心理的ストレス反応 については, 上司を含む全職員で有意に $(p=0.021)$, 上 司以外の職員では, 有意傾向で $(p=0.071)$ 介入効果が 認められた. しかし, 介入群と対照群の HPQについて の群と時点を要因とする 2 元配置分散分析では, その 交互作用項が有意ではなく $(\mathrm{F}$ 值 $=1.24, p=0.267)$, 介入 効果は確められなかった。

2) HPQ 変化量の算出

介入群 442 名のうち, 49 名は調査デー夕が得られず 解析から除外した. 解析を行った 393 名については, 介入前後の HPQ はそれぞれ 66.7 (SE 0.4), 67.1 (SE 0.4) であり変化量は +0.4 (SE 0.4) であった．対照群 136 名 のうち, 11 名はデータが得られず解析から除外した. 解析を行った 125 名については介入前後の HPQ はそ れぞれ 66.9 SE 0.7), 66.5 (SE 0.7) であり，変化量は -0.4(SE 0.7) であった. 以上に基づいて $\Delta \mathrm{HPQ}$ を計算す ると以下となる。休業日数は不明であるため, 計算に 算入しなかった。

$\Delta \mathrm{HPQ}=\frac{\left.(393 \times 0.4+49 \times 0) / 442^{-[125 \times(-0.4)+11 \times 0]}\right] / 136}{(66.7+66.9) / 2}=0.010827\left(\mathrm{SE} 9.4 \times 10^{-3}\right)$ $\Delta \mathrm{HPQ}(95 \% \mathrm{CI})=\left[-7.53 \times 10^{-3}, 0.0292\right]$

3) 費用の算出

高出席率職場の上司の参加人数は 232 名であった. 費用総額および介入群 442 名で除した 1 人当たり費用 


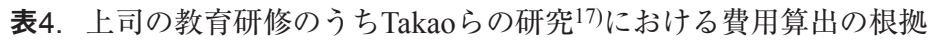

\begin{tabular}{llrr}
\hline 費目 & \multicolumn{1}{c}{ 算出根拠 } & 費用総額 & 介入群 1 人当たり年間* \\
\hline 管理職賃金 & 4.0 時間 $\times 4,000$ 円 $\times 24$ 名** & 384,000 円 & 2,494 円 \\
講師謝金 & 4.0 時間7万円 $\times 1$ 回 & 70,000 円 & 455 円 \\
\hline 合計 & & 454,000 円 & 2,948 円 \\
\hline *費用の総額を介入群 154 名で除した & $* *$ 教育研修に参加した上司の人数は24名であった
\end{tabular}

を表 3-1 に示した．介入群 1 人当たりの費用 5,290 円の うち，管理職の賃金は 4,723 円 (89\%) に上り，講師謝 金は 566 円（11\%）であった。

4) 便益の算出

便益総額, 介入群 442 名で除した 1 人当たり便益, 1 人あたり純便益， 1,000 人当たり純便益打よび費用に対 する便益の比（ROI）を表 3-2 に示した．介入効果の持 続期間については図 2 に示した感度分析を行い，それ ぞれ $95 \%$ 信頼区間を示した，点推定值に基づく 1 人当 たりの純便益は-890-1,310 円, ROI は 0.83-1.24であり, 費用と便益がほぼ同一であったものの，便益の $95 \%$ 信 頼区間はいずれも0 0 を跨いでいた.

3-2. Takao ら (2006) ${ }^{17)}$ の結果

1) 研究の概要

Takao ら (2006) の研究は, 301 名の従業員を持つ国

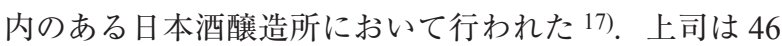
名, 一般職員は 255 名であった。上司 46 名を, 教育研 修を受ける群 $(\mathrm{n}=24)$ と待機群 $(\mathrm{n}=22)$ の 2 群に無作為 に割り付け，一般職員のうち上司が教育研修を受けた 群 (n=154) を介入群と割り付け，上司が待機群であっ た部下 ( $\mathrm{n}=101)$ を対照群として割り付けて比較した。 盲検化は実施していない。 2002 年 10 月に介入群・対照 群ともに事前調查を実施した上で上司の教育研修を実 施し，2003 年 1 月に介入群・対照群ともに事後調查を 実施した。

2) HPQ 変化量の算出

一般職員 $(\mathrm{n}=255)$ のうち 42 名はデー夕不十分であ り解析から除外されていた。デー夕の得られた一般職 員 $(n=213)$ のうち介入群 126 名については, 介入前後 の HPQ はそれぞれ 67.2 (SE 0.67) および 66.7 (SE 0.74) であり変化量は -0.50 であった。対照群 87 名について は, 介入前後の HPQ はそれぞれ 66.9 (SE 0.80) および 66.4 (SE 0.89) であり変化量は -0.50 であった. 従って $\Delta \mathrm{HPQ}=0$ であった．休業日数は報告されていないため, 計算に算入しなかった。

3) 費用の算出

教育研修の上司の参加人数は 24 名であった．費用 総額抒よび介入群 154 名で除した 1 人当たり費用を表 4 に示した。 介入群 1 人当たりの費用 2,948 円のうち, 管理職の貢金が 2,494 円 $(85 \%)$ ，講師謝金は 455 円
（15\%）であった.

4) 便益の算出

$\Delta \mathrm{HPQ}=0$ であったため, 便益は得られなかった，介 入群 1 人当たりの純便益は費用をそのまま反映し, -2,948 円であった.

\section{4. 方法別の費用便益分析の比較}

職場環境改善 ${ }^{14)}$, 個人向けストレスマネジメント教 育 ${ }^{15)}$, 上司の教育研修のうち, Tsutsumi ら (2005) の結 果 ${ }^{16)}$ の各々に损ける，一人当たりの費用拉よび便益の 比較を図 3 に示す. Takao ら (2006) の研究 17) ではどの 感度分析でも便益が 0 円のため, 図には示さなかった. 感度分析 (1)(2)(4)はそれぞれ図1 および図 2 の内容に対 応している。

\section{IV. 考}

本研究でとりあげた先行研究の事例では，3 種類の職 場のメンタルヘルスの第一次予防対策における従業員 1 人当たりの費用は約 2,900-9,700 円であり，介入手法別 に一定の差が認められた。費用の大部分 $(52 \%-89 \%)$ は 対策への参加時の従業員ないし管理職の時給であった. 職場環境改善および個人向けストレスマネジメント教 育では，点推定值において便益は費用を上回り，これ らの職場のメンタルヘルスの第一次予防対策が事業者 にとって経済的な利点がある可能性が示唆された。 ま た，上司の教育研修では点推定值において便益と費用 は概悋同一であり，費用便益分析の観点からは限定的 な効果しか得られない可能性が示唆された，しかしな がら， $\Delta \mathrm{HPQ}$ の $95 \%$ 信頼区間は，いずれの研究でも大 きかった

職場環境改善 14) では介入群で休業日の増加がみられ たものの, 労働生産性の増加が大きく, 総合すると大 きな便益が認められた。職場環境改善の ROI は約 2-3 であり，費用にくらべて 2-3 倍の便益を得られる結果 となった。職場環境改善では職場内からファシリテー ターを養成することや職場構成員の自発性に基づくア クションプランを実施するなど，職員が自立的に共同 作業を行うよう促す特徴がある。この点において，日 常業務にも影響が表れ，作業効率の改善や生産性の向 


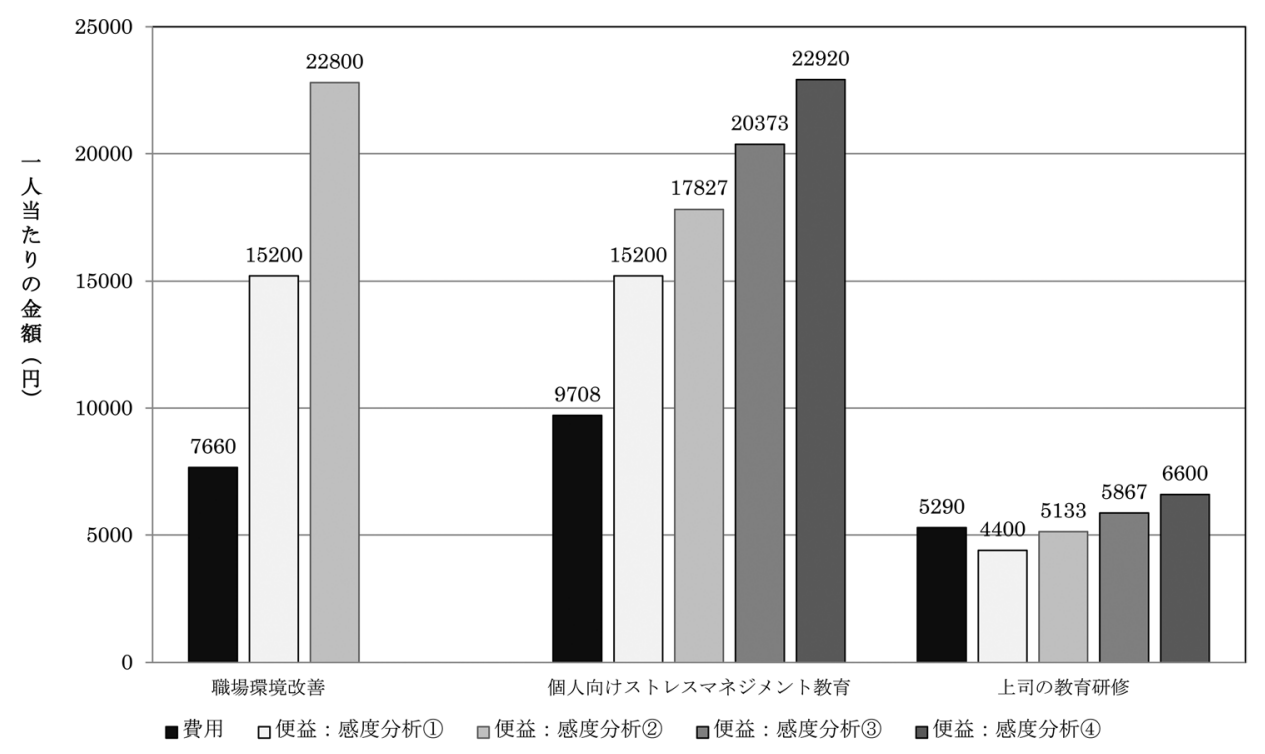

図 3. 職場環境改善 ${ }^{14)}$ ，個人向けストレスマネジメント教育 ${ }^{15)}$ ，および上司の教育研修の うち Tsutsumi らの研究 ${ }^{16)}$ の費用便益分析における，一人当たり費用および便益の比 較. 感度分析(1)(2)(4)はそれぞれ図 1 および図 2 の内容に対応している.上司の教 育研修のうち Takao らの研究) 17) では介入群 1 人当たりの費用金額は 2,948 円であり, 便益は感度分析に関わらず 0 円であった。

上につながった可能性が考えられる．この研究 14)で介 入群に休業日数が増加した理由として, 職場環境改善 により職場でのコミュニケーションが円滑となり，従 業員が病気休業の申し出をしやすくなったことが考え られる。このことにより，生産性の低い presenteeism が回避され，休業することで体調の思わしくない従業 員の休養や回復が促されて，結果的に HPQ で評価され た労働生産性が上がった可能性もある. 職場環境改善 では, 労働生産性への効果が 1 年目まで漸増するとい う仮定 (感度分析(1)) と, 6 ケ月で最大に達しその後 1 年目まで持続するという仮定 (感度分析 (2))の 2 つの 感度分析を実施した。この研究 14) では, 従業員参加の ワークショップによる職場環境改善のアクションプラ ンの作成の後, プランはただちに実施されており，そ の効果は比較的早期から現れている可能性がある. 従っ て, 感度分析(2)の推定の方が適切と考えられる.さら に, 職場環境改善の効果は, 例えば 6 ケ月後の時点では, 1 年後の効果測定時点よりもより大きく上昇していた可 能性もある。このような場合には, 職場環境改善の労 働生産性への効果は感度分析(2)よりもさらに大きくな る可能性もある。

今回とりあげた個人向けストレスマネジメント教育 の研究 15) では, 全てのセッションへの参加者に限ると 労働生産性が有意に増加しており, このグループに着 目した本費用便益分析では ROI が 1.6-2.4 と，いずれ の感度分析でも費用が便益を上回っているという結果
となった。この個人向けストレスマネジメント教育は 6 セッションからなるが, 毎回内容が異なり, 全てを受 講することで一通りの方法を身につけ，これを労働生 産性にも反映させる事ができたと考えられる。しかし, 全ての回に出席する従業員はこのプログラムに途中か ら何らかの効果を感じている者が多いと想定される. 従って, 効果の高く出やすい対象者の結果のみを取り 上げている可能性がある.この点について, 本研究で は費用は延べ参加人数について計上し, 便益は完遂し た従業員のみから得られると仮定して分析を実施した。 このため, 原論文 ${ }^{15)}$ に比べて純便益についてはバイア スの少ない, より厳しい推定になっていると考える. こうした厳しい仮定にもかかわらず，なお，正の純便 益が得られている点は注目に值する. しかし, この論 文15)のもう 1 つの問題点である, 介入群と対照群の割 り付けがランダムでない点については影響を調整でき ていない. 個人向けストレスマネジメント教育では, 6 ケ 月後の事後評価時点から 12 ケ月にかけて効果がどのよ うに減衰するかにより，4つの感度分析を行った．個人 向けのストレスマネジメント教育の効果の持続につい ては, フォローアップセッションがなければその効果 は比較的早期に低下することが報告されている22). 従っ て, 感度分析のうちでは, 12 ヶ月後には効果が 6 ヶ月 後の時点と比べて, なしまで低下する（感度分析(1)）, ないしは $1 / 3$ まで低下する（感度分析(2)）がもっとも現 実的なパターンと考える. 
上司の教育研修 16,17) では，実施費用の大部分 (85\%-89\%) は上司の賃金であった. 上司に介入するこ とによって，部下の生産性の向上を図るという間接的 な手法であるためか, 他の手法よりも労働生産性の改 善は小さかったないし, みられなかった. Tsutsumi ら の研究 16)については, 効果評価が実施された 6 ケ月目 以降の効果の減衰の程度に応じて実施された 4 つの感 度分析では, ROI は 0.8-1.2 と他の手法より低めであり, また, うち 2 つの感度分析では純便益はマイナスであっ た. 先行研究によれば, 上司教育が管理監督者の知識, 行動に与える影響は教育後 6 ケ月まではよく保たれて いる 23). 上司教育の感度分析としては，6 ケ月後の効 果が 12 ケ月後まで持続すると仮定する (感度分析(4)), または $2 / 3$ まで減少すると仮定すること（感度分析(3) が現実的であると考えられる。従って, 上司の教育研 修による ROI は 1.1-1.2 と, いくらか 1 を上回ると想 定される．上司の教育研修からは労働生産性向上によ る大きな便益は望めないが, 概ね費用と便益が同一と いう結果であり，上司の教育研修の少なくとも実施費 用は回収できていることになる。Tsutsumi らの研究 16) はそのデザインが準実験研究であり，そのために上司 が多く教育に参加しやすい職場とそうでない職場の間 に，教育による介入以外の要因によるバイアスがある 可能性がある. 上司の教育研修の費用便益は, 本研究 の分析よりもさらに低い可能性がある. Takao らによる 上司の教育研修の無作為化比較対照試験 ${ }^{17)}$ では, 部下 の労働生産性への効果の点推定值はゼロであり, 上司 の教育研修では労働生産性からの便益は得られないと いう結果であった。他の第一次予防対策の手法に比べ て上司の教育研修は, 労働生産性の増加には一般に結 び付きにくいと考えられる。しかし，上司の教育研修 は, 職場のメンタルヘルス対策として基本に位置づけら れるものであり ${ }^{4)}$, 上司によるサポートは部下のストレ ス反応に良好に作用するという報告もあることから ${ }^{24)}$, 職場のメンタルヘルス対策の実施において重要な役割 を占める上司が適切な知識や態度を身につけるために 必須のものである.上司の教育研修の実施にあたって は, 費用便益分析の結果のみならず，金銭的便益を超 えた上司の教育研修のメリットがあることを事業者は 考慮するべきである.

本研究の費用便益分析においては, いくつかの仮定 をおいて検討を行ったことから, いくつかの留意点が ある. 第一に, 労働生産性は労働者の HPQ あるいは その変法への回答で評価できるとし，これに基づき便 益を産出した. 先行研究においても同様の自己記入式 の生産性の評価を便益に換算した例が見られる ${ }^{12)}$ 。ま た, HPQ を客観的な生産性の指標と比較して妥当性 があるとした研究もある19,20)。しかし， $\Delta \mathrm{HPQ}$ を労
㗢生産性の変化分としてよいかどうかについてはなお 検討が不十分である。また，Presenteeismを定量化す るための質問法は他にも数多く開発され，今回とりあ げた研究で用いられている HPQ の他に, Health and Labor Questionnaire (HLQ), Health Related Productivity Questionnaire-Diary (HRPQ-D), Stanford Presenteeism Scale (SPS), Work Limitation Questionnaire (WLQ) など が知られている6)。これらの異同について，一部につ いては比較研究も行われている 25) が, 網羅的に検証 した知見は得られていない。これらの指標が, HPQよ りも正確な労働生産性の測定法になりうる可能性もあ る. 労働生産性をどのような方法で測定し，どのよう に数量化するかによって費用便益分析の結果は大きく 異なってくる. 労働生産性の指標とその標準化に関す る研究がさらに必要である。第二に，事業者が得られ る便益を，平均年間賞与額を基本にして算出した。年 収でなく年間賞与額を基本とすることが妥当か否かに ついては議論があるかもしれない. 人事労務担当者か らの意見聴取においては, 一般に従業員給与のうち一 定割合は生活保障の意味あいが強いものであり, 能力 給分（賞与）に労働生産性が対応すると考えて妥当では ないかとの意見を得ている，しかし，従業員給与のう ち何\%を能力給と考えるかについては別の考え方もあ り得る(例えば給与総額の $30 \%$ など).ささらに, 労働生 産性の増加による事業者の便益は, 従業員の給与では なく，増加した労働生産性によって企業の業績がどの 程度増加したかであるという考え方もある。本研究で の従業員賞与に基づく便益の算出方法は，ストレスな どによる労働コストの低下をどの程度予防できたかと いう視点に近い。一般に費用便益分析においては, 便 益の算出に困難が伴う事が多いとされており，今後さ らに医療経済学的および労働経済学的観点から検討が 必要と考える，第三に，本研究では費用の計算にあたっ ては範囲を広く，多めに目算し，また便益の算出に当 たっては，いずれの方法も対照群に比べて介入群では 異動・脱落者が多かったにも関わらず，異動・脱落者 では労働生産性がまったく増加しない $(\Delta \mathrm{HPQ}=0)$ など 介入効果を限定的・保守的な推定となるように仮定を 置いて計算した。 また, 通常の産業保健活動は年次単 位で実施・評価を行うので， 1 年間を単位としての費用 便益分析は適切だったと考えているが，例えば，職場 環境改善などでは介入 2 年目以降も介入効果が持続す る可能性があり, 便益は今回の推定よりもさらに増加 する可能性がある，従って，本研究における費用便益 分析の結果は, 実際に産業現場で適用する際の費用便 益比の下限に近いと考えられる. 第四に統計解析上の 留意点である. $\Delta \mathrm{HPQ}$ の $95 \%$ 信頼区間は, いずれの研 究でも大きかった。これらの研究事例において推定さ 
れた費用便益が偶然変動よりも大きなものであるかど うかについては, 本研究からは結論できない.今回の 研究では, いずれの論文も調査個票は得られなかった ため, 論文中に示された HPQ 得点の点推定值および標 準誤差 $(\mathrm{SE})$ を用いて $\Delta \mathrm{HPQ} の 95 \%$ 信頼区間 $(95 \% \mathrm{CI})$ を推計した。この場合, 介入前後の点推定值それぞれ に対して分散の加法性および定数倍の特性を用いて分 散を算出したため, 調査個票を用いて個人毎の変化の 分散から算出した $\Delta \mathrm{HPQ}$ の $95 \% \mathrm{CI}$ よりも広い区間と なる可能性が高い. 感度分析として算出した $\Delta \mathrm{HPQ}$ の 95\% CI がいずれも0を跨いでしまったが, この点の解 釈については個票を用いた時には範囲が狭まり, 統計 的に有意となる可能性があり得ると考えられる。これ らの対策により統計学的に有意な費用便益が得られる かどうかについては, 今後の実際の介入研究において 確かめられる必要がある。

以上の留意点に加え, 本研究の限界として, 職場の メンタルヘルスの第一次予防対策の各手法に関する研 究が 1 ないし 2 つずつしか検索できず, 費用便益分析 の結果が特定の研究の結果に大きく依拠している点が ある. 同一手法であっても職種, 業種などによってそ の費用便益は異なる可能性がある。このため一般化可 能性については限られている. また, 対象とした研究 の研究デザインは無作為化比較試験, 比較対照試験, あるいは準実験研究とまちまちであり, 研究の質(科学 的根拠の水準) にはばらつきがある．異なる研究デザ インによる研究を比較して, 職場のメンタルヘルスの 第一次予防対策の各介入手法の費用便益分析を行って いる点には留意が必要である。ささらに, 個人向けスト レスマネジメント教育および上司の教育研修について の研究では, 疾病休業デー夕は利用できず, 労働生産 性は presenteeismのみから計算されている。こうした 問題は，費用便益分析に使用できるような absenteeism および presenteeismの指標を含めた職場のメンタルヘ ルスの第一次予防対策の介入研究が少ないことから生 じている. 今後実施される職場のメンタルヘルスの第 一次予防対策の介入研究において, absenteeism および presenteeism への効果を測定する事を推奨することで, 職場のメンタルヘルスの第一次予防対策の費用便益分 析をより適切に，より一般化できる形で実施できるよ うになると期待される.

謝辞：本研究は, 平成 23 年度厚生労働科学研究労働安 全衛生総合研究事業「労働者のメンタルヘルス不調の 第一次予防の浸透手法に関する調查研究」(H21- 労働 一般 -001）の一環として実施された.

\section{文 献}

1) 労働者健康福祉機構 大阪産業保健推進センター. 休職か らの職場復帰体制の現実と題一企業へのアンケート調査 から一. [Online]. 2006 [cited 2011 Dec 10]; Available from: URL: http://www.osakasanpo.jp/research/h18.pdf.

2) 厚生労働省. 労働者のこころの健康の保持増進に関する 指針。東京, 2006 .

3) 厚生労働省. 労働者健康状況調査 心の健康対策の実施状 況. 東京, 2007.

4) 川上憲人, 島津明人, 土屋政雄, 堤 明純. 産業ストレ スの第一次予防対策: 科学的根拠の現状とその応用. 産業 医学レビュー. 2008; 20: 175-96.

5) Uegaki K, de Bruijne MC, van der Beek AJ, van Mechelen W, van Tulder MW. Economic evaluations of occupational health interventions from a company's perspective: a systematic review of methods to estimate the cost of health-related productivity loss. J Occup Rehabil 2011; 21: 90-9. [CrossRef] [Medline]

6) 山下未来, 荒木田美香子. Presenteeism の概念分析及び本 邦における活用可能性. 産衛誌 2006; 48: 201-13.

7) Adler DA, McLaughlin TJ, Rogers WH, Chang H, Lapitsky L, Lerner D. Job performance deficits due to depression. Am J Psychiatry 2006; 163: 1569-76. [CrossRef] [Medline]

8) Collins JJ, Baase CM, Sharda CE, et al. The assessment of chronic health conditionson work performance, absence, and total economic impact for employers. JOEM 2005; 47: 547-57. [Medline]

9) Stewart WF, Ricci JA, Chee E, Hahn SR, Morganstein D. Cost of lost productive work time among US workers with depression. JAMA 2003; 289: 3135-44.

10) Tsuchiya M, Kawakami N, Ono Y. et al. Impact of mental disorders on work performance in a community sample of workers in Japan: the World Mental Health Japan Survey 2002-2005. Psychiatr Res (in press).

11）池上直己, 西村周三. 講座 医療経済 - 政策学 第 4 巻医療 技術・医薬品. 東京 : 勁草書房, 2005.

12) Lo Sasso AT, Rost K, Beck A. Modeling the impact of enhanced depression treatment on workplace functioning and costs: a costbenefit approach. Med Care 2006; 44: 352-8. [CrossRef] [Medline]

13) Smoot SL, Gonzales JL. Cost-effective communication skills training for state hospital employees. Psychiatr Serv 1995; 46: 819-22. [Medline]

14) Tsutsumi A, Nagami M, Yoshikawa T, Kogi K, Kawakami N. Participatoryintervention for workplace improvements on mental health and job performanceamong blue-collar workers: a cluster randomized controlled trial. J Occup Environ Med 2009; 51: 554-63. [CrossRef] [Medline]

15) Umanodan R, Kobayashi Y, Nakamura M, Kitaoka-Higashiguchi K, Kawakami N, Shimazu A. Effects of a worksite stress management training program with sixshort-hour sessions: a controlled trial among Japanese employees. J Occup Health 2009; 51: 294-302. [CrossRef] [Medline]

16) Tsutsumi A, Takao S, Mineyama S, Nishiuchi K, Komatsu H, Kawakami N. Effects of a supervisory education for positive mental health in the workplace: a quasi-experimental study. J 
Occup Health 2005; 47: 226-35. [CrossRef] [Medline]

17) Takao S, Tsutsumi A, Nishiuchi K, Mineyama S, Kawakami N. Effects of the job stress education for supervisors on psychological distress and job performance among their immediate subordinates: a supervisor-based randomized controlled trial. J Occup Health 2006; 48: 494-503. [CrossRef] [Medline]

18）厚生労働省. 平成 22 年賃金構造基本統計調査. 東京 : 厚 生労働省, 2010 .

19) Kessler RC, Barber C, Beck A, et al. The World Health Organization Health and Work Performance Questionnaire (HPQ). J Occup Environ Med 2003; 45: 156-74. [CrossRef] [Medline]

20) Kessler RC, Ames M, Hymel PA, et al. Using the World Health Organization Health and Work Performance Questionnaire (HPQ) to evaluate the indirect workplace costs of illness. J Occup Environ Med 2004; 46: S23-S37. [CrossRef] [Medline]

21) 厚生労働省. 平成 23 年就労条件総合調査. 東京 : 厚生労 働省, 2011 .

22) 島津明人, 高田未里, 土屋政雄, 馬ノ段梨乃. 科学的根
拠による EBM ガイドライン開発: 個人向けストレス対策 の普及·浸透. 平成 21 年度厚生労働科学研究費補助金 (労 働安全衛生総合研究事業)「労働者のメンタルヘルス不調 の第一次予防の浸透手法に関する調査研究」分担研究報 告書. 東京 : 厚生労働省, 2010: 10-31.

23) Nishiuchi K, Tsutsumi A, Takao S, Mineyama S, Kawakami N. Effects of an education program for stress reduction on supervisor knowledge, attitudes, and behavior in the workplace: a randomized controlled trial. J Occup Health 2007; 49: 190-8. [CrossRef] [Medline]

24）廣 尚典，森 晃爾，鈴木英孝ほか. ストレス対策にお ける管理監督者教育。労働省平成 11 年度「作業関連疾患 の予防に関する研究」報告書. 東京 : 労働省, 2000: 25571.

25) Sanderson K, Tilse E, Nicholson J, Oldenburg B, Graves N. Which presenteeism measures are more sensitive to depression and anxiety? J Affect Disord 2007; 101: 65-74. [CrossRef] [Medline] 
Appendix. WHO Health and Work Performance Questionnaire Short Form日本語訳

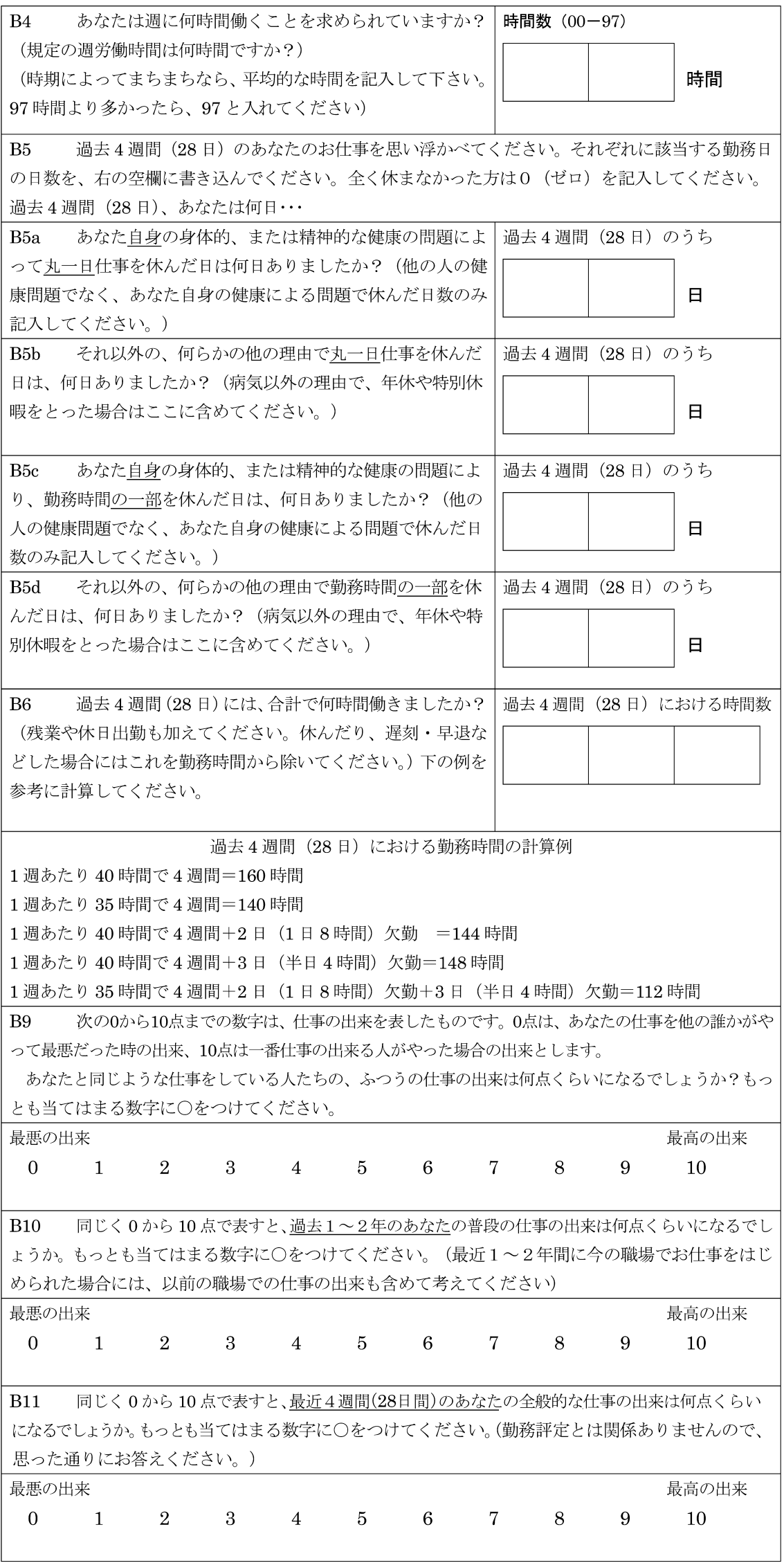




\title{
Cost-Benefit Analysis of Primary Prevention Programs for Mental Health at the Workplace in Japan
}

\author{
Kensuke Yoshimura ${ }^{1}$, Norito Kawakami ${ }^{1}$, Akizumi Tsusumi ${ }^{2}$, Akiomi Inoue ${ }^{3}$, Yuka KobaYashi ${ }^{4}$, Ayano Takeuchi ${ }^{5}$ \\ and Takashi FuKUDA ${ }^{6}$ \\ ${ }^{1}$ Department of Mental Health, Graduate School of Medicine, The University of Tokyo, 7-3-1 Hongo, Bunkyo-ku, Tokyo 113- \\ 0033, Japan \\ 2 Department of Public Health, Kitasato University School of Medicine, Japan \\ ${ }^{3}$ Department of Mental Health, Institute of Industrial Ecological Sciences, University of Occupational and Environmental Health, \\ Japan \\ ${ }^{4}$ Honda Motor Corporation, Japan \\ ${ }^{5}$ Department of Biostatistics, Graduate School of Medicine, The University of Tokyo, Japan \\ ${ }^{6}$ National Institute of Public Health, Japan
}

Objectives: To determine the cost-benefits of primary prevention programs for mental health at the workplace, we conducted a meta-analysis of published studies in Japan. Methods: We searched the literature, published as of 16 November 2011, using the Pubmed database and relevant key words. The inclusion criteria were: conducted in the workplace in Japan; primary prevention focus; quasi-experimental studies or controlled trials; and outcomes including absenteeism or presenteeism. Four studies were identified: one participatory work environment improvement, one individual-oriented stress management, and two supervisor education programs. Costs and benefits in yen were estimated for each program, based on the description of the programs in the literature, and additional information from the authors. The benefits were estimated based on each program's effect on work performance (measured using the WHO Health and Work Performance Questionnaire in all studies), as well as sick leave days, if available. The estimated relative increase in work performance (\%) in the intervention group compared to the control group was converted into labor cost using the average bonus (18\% of the total annual salary) awarded to employees in Japan as a base. Sensitive analyses were conducted using different models of time-trend of intervention effects and $95 \%$ confidence limits of the relative increase in work performance. Results: For the participatory work environment improvement program, the cost was estimated as 7,660 yen per employee, and the benefit was 15,200-22,800 yen per employee. For the individual-oriented stress management program, the cost was 9,708 yen per employee, and the benefit was 15,200-22,920 yen per employee. For supervisor education programs, the costs and benefits were respectively 5,209 and 4,400-6,600 yen per employee, in one study, 2,949 and zero yen per employee in the other study. The $95 \%$ confidence intervals were wide for all these studies. Conclusions: For the point estimates based on these cases, the participatory work environment improvement program and the individual-oriented stress management program showed better cost-benefits. For the supervisor education programs, the costs were almost equal to or greater than the benefits. The results of the present study suggest these primary prevention programs for mental health at the workplace are economically advantageous to employers. Because the $95 \%$ confidence intervals were wide, further research is needed to clarify if these interventions yield statistically significant cost-benefits.

(San Ei Shi 2013; 55: 11-24) 